\title{
FAKTOR PENYEBAB KETIDAKMAMPUAN PETANI MEMENUHI PERMINTAAN BABYBUNCIS UNTUKPT. ALAMANDA SEJATI UTAMA SERTASTRATEGI UNTUK MENGATASINYA (Studi Kasus Kelompok Tani Tauhid, Kabupaten Bandung Barat)
}

\author{
NUR ANNISA RIZKITA KARTIWA ${ }^{1)}$, ENDAH DJUWENDAH ${ }^{2)}$
}

\author{
1) Mahasiswa Program Studi Agribisnis \\ ${ }^{2)}$ Staf Pengajar Program Studi Agribisnis \\ Program Studi Agribisnis Fakultas Pertanian \\ Universitas Padjadjaran, Jatinangor Bandung 40600 \\ Email :annisarizkita18@gmail.com ; endah.djuwendah@unpad.ac.id
}

\begin{abstract}
Baby Kenya bean is a bean types that has a good prospects, it has successfully entered the export market. Poktan Tauhid which is a part of the Farmers Group (Gapoktan) Lembang Agri are the farmers group who grows baby kenya bean. The aim of this research are to know the causative factors of farmer that led to an inability to meet the demand for the baby kenya bean for PT. Alamanda Sejati Utama and determine the accurate strategy which can be implemented in Poktan Tauhid to overcome the problems. The research design is qualitative with descriptive analysis technique with fishbone diagrams and analysis of operation strategies with QSPM. The results of the research indicates that a very problematic technical factors among others are the weather conditions, pest and plant disease. While non-technical factors that is very problematic isthe harvest labor. In addition, technical factors that enter into the troubled category are technology, seeds, water availability andthe wind. The alternative strategy that can be implemented in Poktan Tauhid Backward Integration.The implication of this alternative strategy is enabling Poktan Tauhid to better control the process to reschedule planting schedules for every babykenya bean farmer. Moreover, counseling should be given more frequently, related to technologies and the prevention of pests and diseases naturally.
\end{abstract}

Keyword :Causative factors, alternative strategy, baby kenya bean

\section{PENDAHULUAN}

Sub sektor hortikultura merupakan salah satu sub sektor yang memberikan kontribusi pada Produk Domestik Bruto (PDB) pertanian. Berdasarkan data BPS (2010), sub sektor ini berkontribusi rata-rata 13,72 persen setiap tahunnya pada periode 2005 hingga 2009 pada PDB pertanian.

Komoditas hortikultura meliputi sayuran, buah-buahan, tanaman hias, dan biofarmaka.Berdasarkan data Pusdatin Kementan (2011), Produk Domestik Bruto Hortikultura setiap tahunnya cenderung bertambah untuk periode 20052010.Begitu juga PDB untuk komoditas sayuran yang selalu meningkat periode 2005-2010.Kenaikan terbesar terjadi pada tahun 2007 ke 2008 sebesar 10,23 persen. Hal ini menunjukkan bahwa PDB komoditas sayuran akan selalu meningkat dan bahwa sayuran merupakan komoditas yang prospektif.

Salah satu jenis sayuran yang perlu dikembangkan dan memiliki prospek yang baik yakni buncis.Buncis (Phaseolus vulgaris L.) merupakan salah satu jenis 
sayuran yang memiliki berbagai manfaat yang baik untuk kesehatansehingga masyarakat Indonesia gemar mengkonsumsinya sebagai bahan makanan.

Berdasarkan data Kementan (2015), kebutuhan masyarakat akan buncis cenderung naikdari tahun ke tahun.Pemakaian buncis dalam negeri 96,80 persen digunakan sebagai bahan makanan.Selain itu digunakan sebagai pakan ternak dan bibit untuk penanaman buncis selanjutnya. Namun produksi buncis dalam negeri belum bisa memenuhi penyediaan buncis Indonesia.Penyediaan buncis berfluktuasi setiap tahunnya di periode tahun 2009-2013 dengan kenaikan terbesar terjadi pada tahun 2009 ke 2010 sebesar 15,71 persen. Selain itu terjadi penurunan penyediaan buncis pada tahun 2011 ke 2012 sebesar 2,90 persen.

Berdasarkan data BPS (2015), produksi buncis dalam negeri berfluktuatif setiap tahunnya, kenaikan volume produksi terbesar terjadi pada tahun 2010 sebesar 15,62 persen. Namun pada tahun 2012 dan 2014 mengalami penurunan produksi masing-masing sebesar 3,73 persen dan 3,62 persen.Guna memenuhipenyediaan buncis untuk kebutuhan masyarakat, pemerintah melakukan impor buncis. Impor buncis menurun hingga tahun 2012 tetapi kemudian naik kembali pada tahun 2013. Hal ini menunjukkan bahwa terdapat peluang berkembangnya usahatani buncis guna meningkatkan produksi serta memenuhi kebutuhan masyarakat akan buncis dalam negeri.

Provinsi Jawa Barat merupakan sentra produksi buncis terbesar dibandingkan provinsi lainnya di Indonesia dengan kontribusi sebesar 27,08 s.d 31,19 persen terhadap produksi nasional selama periode tahun 2009-2014.Setiap tahunnya kontribusi Jawa Barat berubah-ubah karena volume produksi buncis di Jawa Barat pun berfluktuasi. Volume produksi yang fluktuatif ini disebabkan karena berbagai hal mulai dari perubahan cuaca yang ekstrim, serangan hama dan penyakit tanaman, hingga konversi lahan pertanian ke non-pertanian(BPS, 2015).

Menurut ACDI VOCA dalam Siregar (2011), salah satu jenis buncis yang sedang berkembang dan berhasil di ekspor ke wilayah Singapura yakni jenis babybuncis. Pemetaan sentra produksi komoditas baby buncis di Jawa Barat terletak di Kabupaten Bandung dan Kabupaten Bandung Barat. Salah satu kelompok tani yang mengusahakan komoditas baby buncis yakni Kelompok Tani (Poktan) Tauhid yang merupakan bagian dari Gapoktan Lembang Agri.

Masalah yang sedang dihadapi oleh Poktan Tauhid yakni belum mampunya petani di Poktan Tauhid untuk memenuhi permintaan babybuncis (untuk PT. Alamanda Sejati Utama).Menurut Bapak Dodih, ketua Poktan Tauhid pada awalnya jumlah barang yang diminta PT. Alamanda Sejati Utama sebesar 100 $\mathrm{kg} /$ hari. Karena belum sanggup maka dalam perjanjian kerja sama, Poktan Tauhid melalui Gapoktan Lembang Agri hanya akan mengirim $50 \mathrm{~kg} / \mathrm{hari}$ untuk babybuncis ke PT. Alamanda Sejati Utama (pemintaan selama sebulan diakumulasikan sebesar $1500 \mathrm{~kg}$ ). Tetapi setelah diakumulasikan selama sebulan, Poktan Tauhid belum bisa memenuhi permintaan.

Pada tahun 2014 Poktan Tauhid hanya bisa memenuhi permintaan PT. Alamanda Sejati Utama sebesar 65,82 persen. Sedangkan dari seluruh jumlah baby buncis yang dikirimkan ke PT. Alamanda Sejati Utama sebanyak 15,97 persen ditolak. Pada tahun 2015 pun petani di Poktan Tauhid belum bisa memenuhi permintaan babybuncis untuk PT. Alamanda Sejati Utama. Kelompok tani Tauhid hanya bisa memenuhi permintaan sebesar 83,9 persen. Sedangkan dari 
total jumlah baby buncis yang dikirimkan ke PT. Alamanda Sejati Utama sebanyak 83,81 persen diterima dan 16,19 persen ditolak.

Masalah belum mampunya petani di Poktan Tauhid memenuhi permintaan baby buncis untuk PT. Alamanda Sejati Utama ini dapat disebabkan oleh berbagai faktor baik faktor teknis maupun nonteknis. Untuk mengetahui secara pasti mengenai berbagai faktor-faktor yang menyebabkan masalah ketidakmampuan petani memenuhi permintaan baby buncis untuk PT. Alamanda Sejati Utama maka perlu dilakukan penelitian lebih lanjut agar selanjutnya dapat disusun stategi di tingkat Poktan Tauhid yang dapat diaplikasikan guna mengatasi masalah tersebut sehingga tidak terjadi kembali dikemudian hari.

\section{METODE PENELITIAN}

Desain yang digunakan dalam penelitian ini adalah desain kualitatif sedangkan teknik penelitian adalah studi kasus (case study).Penelitian dilaksanakan di Kelompoktani Tauhid yang memiliki lokasi usahatani di tiga desa yaitu Cikidang (Dusun Pengkolan, Cikareumbi, dan Cisalasih), Cikole (Dusun Karang Tengah), dan Langensari (Dusun Ngampay) Kecamatan Lembang, Kabupaten Bandung Barat. Pemilihan tempat penelitian dilakukan secara sengaja(purposive)karena kondisi sumberdaya alam di Kecamatan Lembang cocok untuk budidaya babybuncis sehingga secara teori hasil panen bisa maksimal serta seluruh produk baby buncis sudah berorientasi ekspor melalui PT. Alamanda Sejati Utama. Namun masihterkendala ketidakmampuan petani dalam memenuhi permintaan babybuncis tersebut.

Datayang diperoleh dari hasil observasi dan wawancara dianalisis secara deskriptif kualitatif. Faktor penyebab ketidakmampuan petani memenuhi permintaan baby buncisuntuk PT Alamanda diidentifikasi dengan bantuan alat analisis diagram fishbone. Menurut Asmoko (2014), ada 5 langkah dalam penyusunan diagram fishbone dapat yaitu membuat kerangka diagram fishbone, merumuskan masalah utama, mencari faktor-faktor utama yang berpengaruh atau berakibat pada permasalahan, menemukan penyebab untuk masing-masing kelompok penyebab masalahdan menggambarkannya dalam diagram fishbone.Sedangkan strategi operasi Kelompoktani Tauhid untuk mengatasi ketidakmampuan produksi dianalisis menggunakan matrik Internal Factor Evaluation (IFE), matrik External Factor Evaluation (EFE) dan Quantitative Strategic Planning Matrix (QSPM).Menurut David (2011), Matriks QSPM (Quantitative Startegic Planning Matrix) digunakan untuk pengambilan keputusan dengan mengevaluasi dan memilih strategi terbaik yang paling cocok dengan lingkungan internal dan eksternal organisasi.Selanjutnya hasil analisis data disajikan secara deskriptif kualitatif.

\section{HASIL DAN PEMBAHASAN}

Faktor Penyebab Ketidakmampuan Petani Memenuhi Permintan baby buncisUntuk PT Alamanda Sejati Utama

Babybuncis merupakan jenis komoditas buncis yang umur atau usia panen lebih singkat(sekitar 45-50 hari setelah tanam) dari pada buncis biasa. Spesifikasi kualitas baby buncis yang diinginkan oleh PT Alamanda Sejati Utama adalah sebagai berikut : memiliki panjang $10-13 \mathrm{~cm}$, bentuk buah reatif lurusbentuk polong buah bulat sampai agak lebar dan berwarna hijau tua, buah 
tidak layu, tidak memiliki bercak hitam, bebas dari hama dan penyakit serta terhindar dari kerusakan mekanik (lecet/memar akibat terkena alat panen, alat angkut dan benda lainnya).

Hasil panen baby buncis dari lahan petani dikumpulkan menggunakan ember, lalu dipacking ke dalam kantong plastik bening untuk $30 \mathrm{~kg}$ babybuncis dan segera dikirimkan ke kantor sekretariat Gapoktan Lembang Agri untuk ditimbang dan dicatat. Kemudian dibawa ke gundang PT Alamanda dengan menggunakan Truk cargo yang dilengkapi pendingin. Pada saat sampai di gudang,pihakPT Alamanda Sejati Utama menyortirnya.Baby buncis yang sesuai kualitas dibayar oleh PT Alamanda sebesar Rp 12.000 s.d 13.000 per Kg pada tahun 2015 dan Rp 13.000 s.d 14.000 pada awal tahun 2016 dengan sistem pembayaran tunda selama 2 minggu setelah barang dikirim oleh Gapoktan Lembang Agri. Apabila ada baby buncis yang tidak sesuai dengan spesifikasi (reject) maka dikembalikan kepada Gapoktan Lembang Agri dan selanjutnya Gapoktan akan menjualnya ke pasar tradisional.

Dalam Mou antara Gapoktan Lembang Agri dan PT. Alamanda Sejati Utama terdapat keadaan memaksa (force majure) dalam hal ini adalah peristiwa diluar kehendak petani seperti bencana alam, kebakaran, gagal panen, dan hal-hal yang berkenaan langsung dan berakibat menghambat kegiatan pelaksanaan penanaman. Apabila terjadi force majure maka pihak Gapoktan Lembang Agri tidak wajib memberikan ganti rugi berupa apapun kepada pihak PT. Alamanda Sejati Utama.

Menurut Mahananto,dkk(2009) terjadinyaperbedaan hasil (yield gap) dalam usahatani disebabkan oleh dua faktor yaitu faktor non-teknis (sosial ekonomi) dan faktor teknis (biologi). Faktor non-teknis (sosial ekonomi) yaitu keadaan yang menghalangi petani untuk menggunakan teknologi yang direkomendasikan, yang meliputi: pengetahuan petani sebagai indikatornya adalah pengalaman petani didalam berusahatani dan prasarana transportasi sebagai indikatornya adalah jarak lahan garapan dengan tempat tinggal petani. Sedangkan faktor (teknis) biologi sebagai indikatornya adalah ketersediaan air irigasi. Faktor non-teknis (sosial ekonomi) dan faktor teknis (biologi) tersebut akan mempengaruhi pertimbangan petani sebagai menajer untuk mengambil keputusan dalam penggunaan input sehingga akan menentukan tingkat produksi dan produktifitas usahatani.

Ketidakmampuan petani memenuhi permintaan babybuncis ini disebabkan oleh faktor teknis (biologi) dan non-teknis (sosial ekonomi). Faktor teknis adalah factor penyebab yang berasal dari kondisialam (cuaca, bencana alam, angin) dan bukan berasal darikondisi alam (alat usahatani, pestisida, pupuk, benih baby buncis, ketersediaan air, teknologi, dan organisme penganggu tanaman). Sedangkan faktor non-teknis merupakan faktor penyebab yang bersifat sosial ekonomi yang secara teori berpengaruh kepada usahatani. Adapun faktor yang diasumsikan kedalam faktor non-teknis antara lain faktor sosial (tenaga kerja) serta ekonomi (modal dan harga jual). Selain itu faktor penyebab dibagi menjadi dua kategori masalah, yakni kategori sangat bermasalah dan bermasalah.Perbedaan dari kedua kategori tersebut terletak di seberapa seringnya masalah tersebut dialamipetani baby buncis.Serta seberapa gentingnya masalah tersebut dan pengaruhnya terhadap kegiatan usahatani petani baby buncis.Faktor tersebut disajikan pada Gambar 1. 


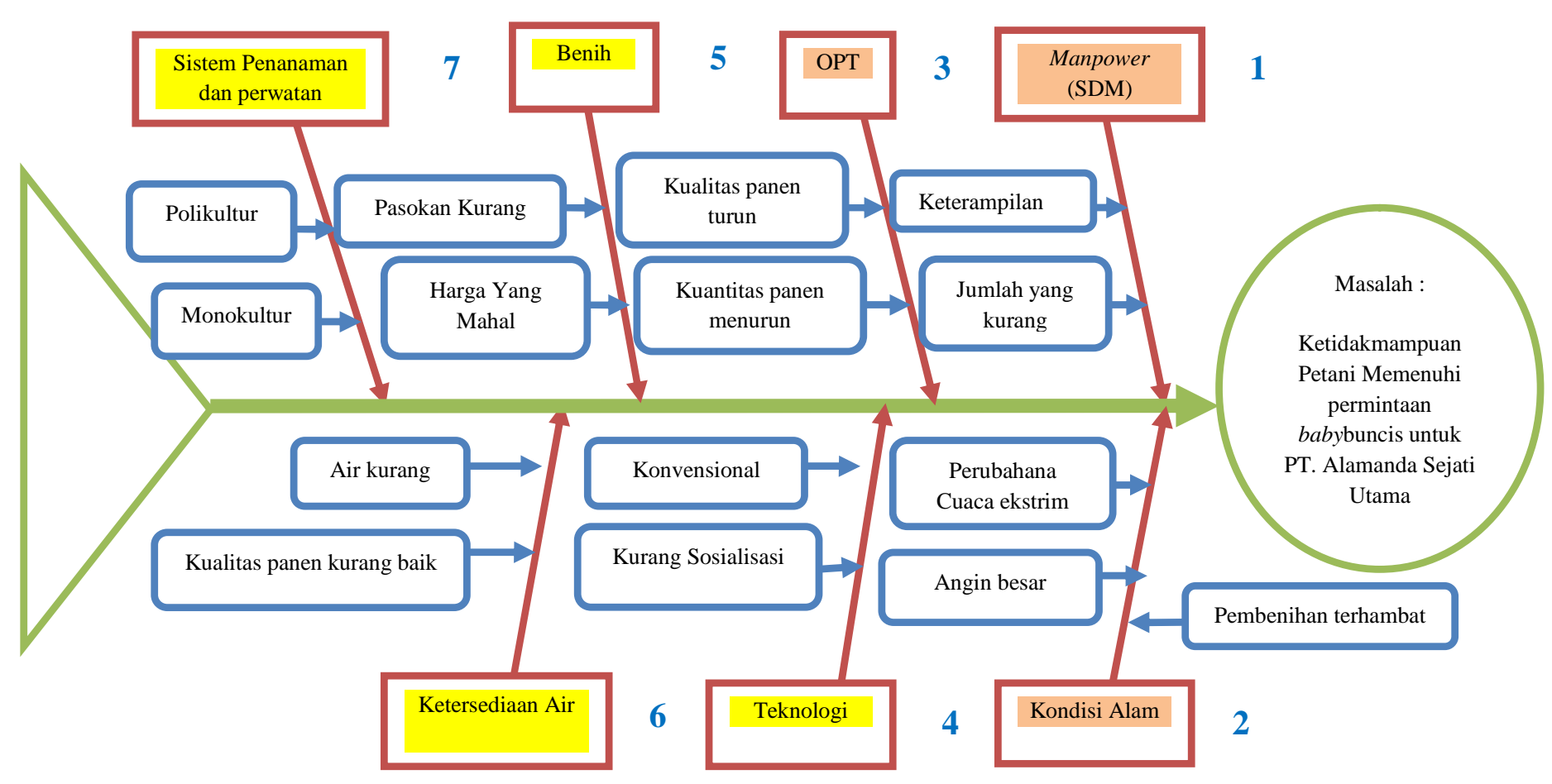

Gambar 1. Faktor Penyebab Petani Di Kelompok Tani Tauhid tidak dapat Memenuhi Permintaan BabyBuncis

\section{1) Sumber Daya Manusia}

Faktor penyebab pertama yang ada dalam usahatani baby buncis di poktan Tauhid yakni faktor non-teknis (sosial ekonomi) berupa ketersediaan tenaga kerja (buruh tani) panen.Hal ini dikarenakan terdapat ketidakseimbangan antara jumlah petani dan buruh tani. Seperti contoh diambil dari data Desa Cikidang tahun 2014, sebesar 52,317 persen matapencaharian penduduk di Desa Cikidang adalah petani sehingga setiap petani memiliki lahan masing-masing dan membutuhkan tenaga kerja untuk melakukan kegiatan mulai dari pengolahan lahan hingga panen. Tetapi penduduk yang memiliki matapencaharian sebagai buruh hanya ada 27,1 persen. Sehingga jelas krisis untuk tenaga kerja khususnya untuk panen terjadi di petani baby buncis.

Sebanyak 82,4 persen dari seluruh petani baby buncis menyatakan bahwa kurangnya ketersediaan tenaga kerja panen menjadi hal yang sangat bermasalah bagi petani. Ada dua macam tenaga kerja yang digunakan oleh petani baby buncis, yakni Tenaga Kerja Luar Keluarga (TKLK) dan Tenaga Kerja Dalam Keluarga (TKDK). Sebanyak 70,58 persen petani baby buncis menggunakan jasa TKLK. Sedangkan 29,42 persen menggunakan jasa TKDK. Tetapi pada saat panen, petani baby buncis yang menggunakan tenaga kerja keluarga tetap menggunakan tenaga buruh tani dengan meminjam dari petani yang lain untuk membantu dalam proses pemanenan babybuncis.

Buruh panen mengeluh mengenai cara panen baby buncis yang berbeda dengan cara panen buncis yang biasa. Ketika memanen mereka harus dalam posisi berjongkok sepanjang hari karena tinggi tanaman babybuncis hanya \pm satu meter.Selain posisi yang berjongkok, tenaga kerja panen dituntut untuk memetik dengan hati-hati agar pangkal baby buncis ikut terpetik supaya umur simpan baby 
buncis dapat lebih lama.Sehingga tidak semua orang dapat memanen baby buncis dengan baik.Panen babybuncis yang ideal dilakukan seminggu empat kali. Apabila babybuncis dibiarkan tumbuh terus menerus, tidak dipanen setelah 45-50 hari setelah tanam (HST) maka tidak akan masuk kriteria/spesifikasi yang diminta oleh PT. Alamanda Sejati Utama. Selain itu, tenaga kerja yang kurang terampil pun menyebabkan jumlah panen yang diterima menjadi lebih sedikit.

Kurangnya ketersediaan tenaga kerja panen juga menyebabkan petani enggan memperluas lahannya untuk ditanam baby buncis karena lahan yang lebih luas membutuhkan tenaga kerja yang lebih banyak pula. Dengan terbatasnya jumlah buruh panen ditambah cara panen yang lebih sukar dari panen komoditas yang lain membuat petani babybuncis mengurungkan niat untuk memperluas lahan usahatanibabybuncis (penanaman dibatasi) sehingga berpengaruh langsung kepada hasil panen babybuncis yang belum optimal baik dari kuantitas maupun kualitas.

\section{2) Kondisi Alam}

Kondisi alam menjadi faktor teknis (biologi-alam) yang berpengaruh kepada hasil panen dan kegiatan usahatani babybuncis. Hal ini terbukti dari 70,6 persen petani baby buncis yang menjawab bahwa cuaca merupakan faktor yang sangat mempengaruhi kegiatan usahataninya.

Dewasa ini, sulit untuk memprediksikan pada bulan apa akan terjadi musim hujan dan musim kemarau. Petani baby buncis biasanya menanam babybuncis pada awal musim hujan sehingga masalah kekurangan air di lahan tidak akan terjadi. Karena semua petani baby buncis tidak menyiram tanaman babybuncis pada saat musim hujan. Selain itu apabila mengetahui cuaca yang akan terjadi pada bulan $\mathrm{X}$ petani dapat mempersiapkan stok benih untuk musim hujan. Tetapi karena tidak teraturnya musim membuat beberapa petani baby buncis kewalahan dengan kurangnya stok benih di Gapoktan Lembang Agri.

Selain cuaca yang ekstrim, angin besar saat terjadi hujan pun dapat berdampak buruk untuk tanaman.Angin yang besar dapat membuat tanaman menjadi miring (tidak tegak seperti seharusnya).Sehingga berpengaruh terhadap pertumbuhan tanaman kedepannya dan berujung kepada hasil panen yang kurang maksimal.

\section{3) Organisme Penganggu Tanaman (OPT)}

Organisme Pengganggu Tanaman (OPT) yang sering menyerang yakni ulat buah (Hiliothis armigera) dan penyakit busuk lunak akar (bakteri Erwinia carotopora). Ulat polong menyerang polong kemudian menyebabkan baby buncis menjadi berlubang.Pada awalnya ulat tidak terlihat karena berada di dalam polong. Tetapi lama kelamaan polong babybuncis akan berlubang sehingga tidak masuk kriteria barang yang diterima oleh PT. Alamanda Sejati Utama.

Penyakit busuk lunak akar sering menyerang tanaman saat musim hujan. Apabila dalam satu lahan sudah ada satu tanaman babybuncisyang terserang penyakit busuk luna akar, maka harus segera dicabut tanaman yang terserang karena dikhawatirkan akan menular pada tanaman baby buncis yang ada di sebelahnya. Sebanyak 64,71 persen petani baby buncis setuju bahwa OPT membuat kualitas dan kuantitas hasil panen menurun. Hal tersebut dapat diminimalisir dengan pencegahan sebelum hama dan penyakit menyerang.

\section{4) Teknologi}

Penggunaan teknologi dikalangan petani baby buncis masih sangat minim.Hal ini dikarenakan kurangnya sosialisasi dari penyuluh pertanian setempat mengenai 
teknologi dalam usahatani baby buncis. Sehingga 94,17 persen atau enam belas petani baby buncis menyatakan belum menerapkan teknologi tepatguna seperti penggunaan Kultivator dalam pengolahan lahan, sistem irigasi tetes, dan teknologi perekat untuk mencegah rontok bunga.

\section{5) Benih}

Siregar (2011) menyatakan bahwa keberhasilan dalam membudidayakan suatu komoditas terdapat pada benih yang digunakan.Oleh karena itu, benih harus dipilih dengan baik serta disesuaikan dengan keadaan iklim daerah budidaya.

Sebanyak 64,70 persen petani menyatakan terdapat masalah pada benih, mulai dari harga, kualitas, hingga ketersediaan stok benih saat musim tertentu. Menurut Bapak Dodih, salah seorangpetani sekaligus ketua Poktan Tauhid, pihak gapoktan pernah mengalami krisis benih dimana gapoktan sama sekali tidak memiliki persediaan benih. Hal ini terjadi pada bulan Maret 2015 dan April 2015.

Adapun penyebab keterbatasan stok benih babybuncis ini karena pada saat musim hujan, pembenihan tidak dilakukan dengan alasan karena itensitas penyinaran sinar matahari pada musim hujan sangat minim sehingga kualitas benih menjadi kurang baik.

Pada tahun 2014 pernah dilakukan pembenihan untuk babybuncis saat musim hujan. Tetapi hasil kurang maksimal, sehingga pada saat akan ditanam oleh petani baby buncis, benih bewarna kehijau-hijauan dan tidak tumbuh pada saat ditanam dalam tanah. Hal tersebut tentu berdampak langsung kepada jumlah tanaman yang ditanam oleh petani baby buncis dan jumlah hasil panen.

Harga benih pun seiring waktu menjadi semakin mahal.Hal ini cukup memberatkan beberapa petani baby buncis yang tidak membuat benih sendiri.Tetapi pihak Gapoktan meringankan beban petani dengan memberikan pinjaman benih babybuncis dan petani bisa membayarnya saat setelah panen tiba.

\section{6) Ketersediaan Air}

Pada saat musim kemarau sebagian daerah mengalami kesulitan mendapatkan air, hal tersebut dirasakan pula oleh petani baby buncis di tiga desa dan lima dusun. Sebanyak 47,06 persen petani baby buncis berpendapat bahwa air merupakan masalah yang harus diatasi. Karena, apabila baby buncis kekurangan air akan berpengaruh kepada kualitas hasil panen, bentuk buah menjadi tidak lurus (melengkung) dan cenderung lebih pendek dari ukuran seharusnya, yakni kurang dari $13 \mathrm{~cm}$ sehingga tidak sesuai dengan spesifikasi/kriteria baby buncis yang diminta oleh PT. Alamanda Sejati Utama, yakni bentuk relatif lurus.

\section{7) Sistem Penanaman}

Sistem penanaman yang digunakan didominasi ( 82,35 persen) oleh sistem polikultur. Sedangkan 17,64 persen petani menggunakan sistem monokultur. Petani yang memilih menggunakan sistem penanaman polikultur karena menurut mereka dengan menanam lebih dari satu tanaman dalam satu lahan dapat membuat petani mendapat hasil panen saat tanaman satunya belum masuk ke waktu panen. Petani menanambaby buncis bersamaan dengan lettuce head, tomat, timun, brokoli, atau tomat. Sedangkan petani yang menggunakan sistem penanaman monokultur disebabkan menurut mereka dengan hanya menanam satu jenis tanaman akan membuat mereka lebih fokus pada perawatan dan kualitas serta kuantitas hasil panen. 


\section{Strategi Operasi dalam mengatasi Ketidakmampuan Petani Memenuhi PermintaanBabyBuncis dari PT Alamanda Sejati Utama}

a) Tahap Masukan (Input Stage)

Faktor kunci tersebut berdasarkan pembobotan oleh ketua, bidang produksi, dan sarana produksi Poktan Tauhid.Setelah diberi bobot, masing masing faktor utama internal (kekuatan dan kelemahan) diberi rangking oleh ketua, bidang produksi, dan sarana produksi Poktan Tauhid.Kemudian didapatkan skor akhir dari Matriks Internal Factor Evaluation (IFE) sebesar 2.503.Hal ini menunjukkan posisi Poktan Tauhid dalam keadaan rata-rata.

Faktor-faktor eksternal kunci yang didapat dari pembobotan dilakukan dan oleh ketua, bagian produksi, dan sarana produksi dari Poktan Tauhid.Setelah itu diberi rangking oleh ketua, bagian produksi, dan sarana produksi dari Poktan Tauhid.Kemudian didapatkan skor akhir dari Matriks External Factor Evaluation (EFE)sebesar 3,033.Hal ini menunjukkan bahwa lingkungan luar dari Poktan Tauhid berada di posisi yang tinggi.

b) Tahap Pencocokan (Matching Stage)

Dalam tahap ini digunakan matriks IE (Internal dan Eksternal) sebagai alat analisis dalam proses pencocokan data yang sesuai dengan Poktan Tauhid.Pada sumbu-x matriks IE, nilai matriks IFE adalah 2,503 sehingga menujukkan posisi internal Poktan Tauhid adalah rata-rata. Demikian pula pada sumbu-y total nilai matriks EFE didapatkan sebesar 3,033 yang berarti posisi eksternal Poktan Tauhid adalah Tinggi .Sehingga dalam matriks IE, posisi Poktan Tauhid berada di sel II.

Total Skor IFE

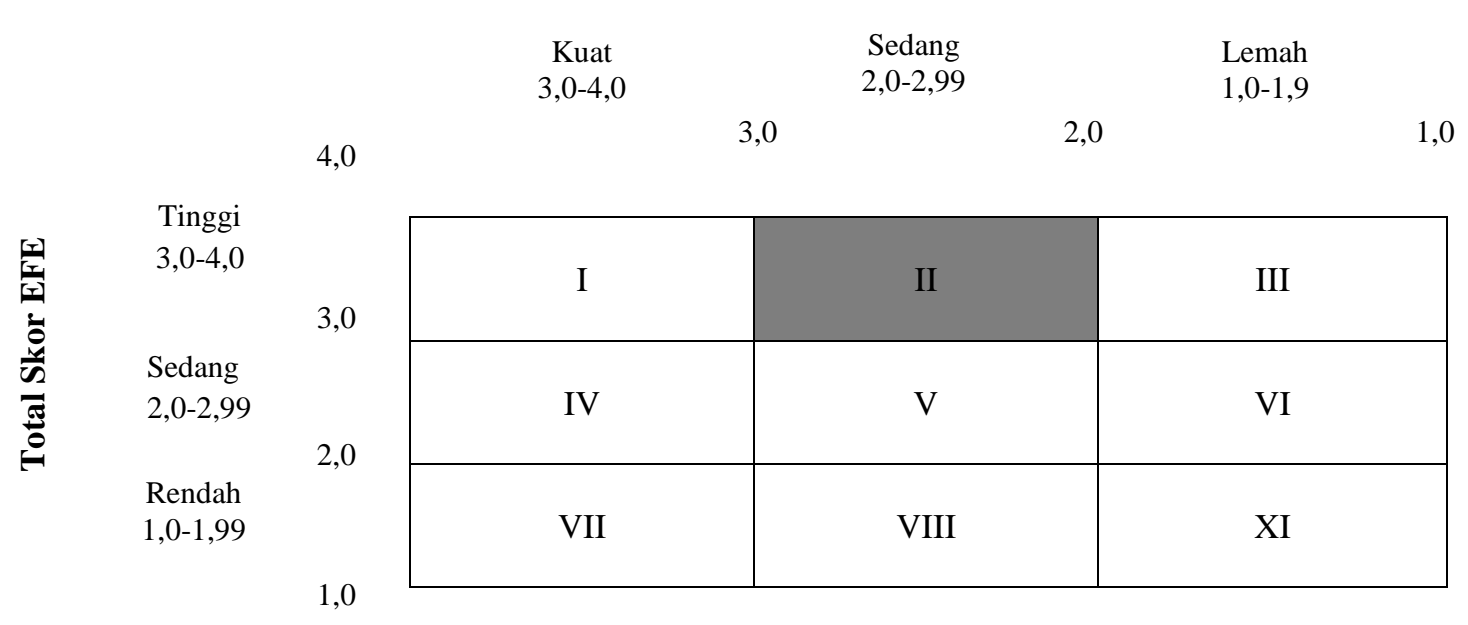

Gambar 2. Matriks Internal-Eksternal Kelompok Tani Tauhid

Menurut David (2011), divisi-divisi yang masuk dalam sel I, II, atau IV dapat digambarkan sebagai tumbuh dan membangun (grow and build). Strategi itensif (penetrasi pasar, pengembangan pasar, dan pengembangan produk) atau integratif (integrasi ke depan, integrasi ke depan, dan integrasi horizontal) bisa menjadi yang paling tepat bagi divisi-divisi ini.

c) Tahap Pengambilan Keputusan (Decision Stage)

Tahap pengambilan keputusan ini menggunakan Matriks QSPM (Quantitative Strategy Planning Matrix) untuk pengambilan keputusan 
dengan mengevaluasi dan memilih strategi terbaik dari enam strategi alternatif.Berdasarkan analisis matriks QSPM didapat strategi terbaik adalah strategi Integrasi ke Belakang dengan nilai akhir 4,99. Menurut David (2011), strategi Integrasi ke Belakang mengupayakan kendali yang lebih besar atas pemasok sebuah organisasi/perusahaan. Strategi tersebut sangat tepat ketika pemasok organisasi/perusahaan yang ada saat ini tidak bisa diandalkan atau tidak mampu memenuhi kebutuhan organisasi/perusahaan.

Dalam hal ini petani babybuncis yang menjadi pemasok babybuncis untuk organisasi yang merupakan wadah dari sekumpulan petani yakni Poktan Tauhid.Petani babybuncis di Poktan Tauhid belum bisa memenuhi permintaan babybuncis untuk buyer utama babybuncis yakni PT. Alamanda Sejati Utama.

Mengacu pada David (2011), berikut ini beberapa alasan mengapa strategi alternatif Integrasi Ke Belakang dapat menjadi strategi yang efektif bagi permasalahan ketidakmampuan petani memenuhi permintaan babybuncis untuk PT. Alamanda Sejati Utama diantaranya:

1) Ketika petani pemasok babybuncis tidak mampu memenuhi permintaan buyer (PT. Alamanda Sejati Utama)

2) Ketika jumlah pemasok (petani babybuncis) sedikit

3) Ketika organisasi perlu memperoleh sumber daya yang dibutuhkan secara cepat seperti sumber daya manusia sebagai tenaga kerja panen babybuncis

Adapun implikasi strategi pada fungsi produksi/operasi untuk strategi alternatif integrasi ke belakangdiantaranya:

1) Memampukan organisasi untuk lebih mengendalikan proses.

Hal ini dapat dilakukan dengan pertemuan (musyawarah) yang lebih sering antara bagian produksi Poktan Tauhid dengan petani babybuncis guna mempererat hubungan antara pihak Poktan Tauhid dengan petani babybuncis. Dalam musyawarah tersebut dapat dibicarakan mengenai pengaturan jadwal tanam babybuncis dari setiap petani.

2) Meningkatkan penggunaan teknologi serta keterampilan yang tinggi melebihi dari yang ada pada saat ini.

- Pengunaan teknologi di tingkat petani babybuncis lebih ditingkatkan lagi seperti penggunaan kultivator untuk mengolah lahan bisa mengurangi jumlah tenaga kerja (buruhtani). Buruhtani lebih lebih sering digunakan saat memasuki musim panen babybuncis, karena panen babybuncis yang memiliki teknik yang berbeda dengan buncis biasa sehingga membutuhkan banyak buruhtani panen dalam pengerjaannya.

- Meningkatkan Intensitas penyuluhan terkait teknologi. Supaya Petani babybuncis tidak hanya mengandalkan cara konvensional dalam kegiatan usahataninya, karena penggunaan teknologi akanmembantu petani meringgankankegiatan usahataninya. Penyuluhan merupakan hal yang penting guna menambahwawasan petani dan keterampilan petani dalam melakukan kegiatan usahatani.

Penyuluhan mengenai perawatan tanaman dan teknik pencegahan Organisme Penganggu Tanaman (OPT) secara alami perlu diinformasikan kepada petani sehingga hasil panennya menjadi lebih baik tanpa serangan hama dan penyakit serta membuat petani tidak ketergantungan terhadap obat-obatan kimia (pestisida anorganik). 


\section{KESIMPULAN DAN SARAN \\ Kesimpulan}

1. Ketidakmampuan petani Poktan Tauhid memenuhi permintaan babybuncis untuk PT. Alamanda Sejati Utama disebabkan oleh faktor teknis (biologialam dan bukan alam) dan non-teknis (sosial ekonomi), dengan dua kategori (sangat bermasalah dan bermasalah). Kategori Sangat bermasalah secara nonteknis (sosial ekonomi) karena jumlah buruhtani panen yang terbatas $(76,50$ persen) dan secara teknis (biologi) Gangguan Organisme Penganggu Tanaman (64,71 persen) dan karena kondisi alam berupa cuaca yang ekstrim (70,60 persen). Kategori Bermasalah secara teknis (biologi) disebabkan oleh penggunaan teknologi yang minim (94,11 persen), pasokan benih yang kurang di bulan tertentu (64,7 persen), ketersediaan air yang kurang di lahan saat musim kemarau (47,06 persen) dan angin yang besar saat hujan (52,94 persen).

2. Berdasarkan analisis matriks Quantitative Strategy Planning Matrix (QSPM)pada Kelompok Tani Tauhid, didapatkan strategi terbaik dari enam strategi alternatif adalah strategi integrasi ke belakang dengan nilai 4,99. Imple-mentasi dari strategi Integrasi ke Belakang ini antara lain dengan cara: (a) memampukan organisasi (Poktan Tauhid) untuk lebih mengendalikan proses melalui pertemuan yang intens antara pengurus Poktan Tauhid bidang produksi dengan petani baby buncis, pengaturan ulang jadwal tanam di bulan tertentu dan (b) Meningkatkan penggunaan teknologi serta keterampilan petani melalui adopsi teknologi usahatani baby buncis, meningkatkan intensitas penyuluhan budidaya baby buncis dan pengendalian OPT.

\section{Saran}

Pengurus Kelompok Tani Tauhid dari setiap bidang sebaiknya lebih aktif lagi dalam kegiatan penyuluhan atau sosialisasi.Pertemuan antar pengurus dan petani anggota lebih sering diadakan guna untuk mempererat hubungan dan kelancaran produksi babybuncis ini.Sebaiknya pihak pengurus bersedia untuk menerima dan menampung saran serta keluhan dari petani (baik petani babybuncis maupun petani komoditas lain) sehingga dapat dilakukan perbaikan di Kelompok Tani Tauhid sendiri. Petani babybuncis sebaiknya melakukan pembenihan secara mandiri sehingga mengurangi permasalahan stok benih yang kurang saat memasuki musim tanam akhir penghujan.

\section{DAFTAR PUSTAKA}

Asmoko, Hindri. 2014. Teknik Ilustrasi Masalah-Fishbone Diagram. Available onlineat

http://www.bppk.depkeu.go.id/bdpimmagelang/images/unduh/teknik_ilust rasi_masalah.pdf

Badan Pusat Statistik. 2010. Perbandingan Nilai PDB Subsektor Hortikultura Terhadap Subsektor Tahun 2005 - 2009 Berdasarkan Harga Berlaku (Trilyun Rupiah). Available online at http://www.bps.go.id

2015. Data Produksi Buncis Tahun 2010-2014. Available online at http://www.bps.go.id/site/resultTab

David, Fred R. 2011. Strategic Management-Manajemen Strategis Konsep (Buku 1 Edisi 12). Jakarta: Penerbit Salemba Empat 
Diperta. 2012. Pemetaan Lokasi Sayuran Hijau Tujuan Ekspor. Available online at http://diperta.jabarprov.go.id/index.php/subMenu/924

Kementan, 2015.Neraca Bahan Makanan Buncis. Available online at http://aplikasi2.pertanian.go.id//konsumsi/tampil_nbm.php

Mahananto,Salyo Sutrisno dan Candra F Ananda2009. Faktor-faktor yang Mempengaruhi Produksi Padi Studi Kasus di Kecamatan Nogosari, Boyolali, Jawa Tengah.Jurnal Wacana Volume 12 No 1 Januri 2009, ISSN.1411-0199. Available online at http://wacana.ub.ac.id/index.php/wacana/article/viewFile/181/158

Siregar, Rio Alexander.2011. Faktor Penentu Utama Produksi Baby Buncis (Phaseolus vulgaris L.)(Skripsi). Jatinangor: Universitas Padjadjaran 